\title{
THE LADY MARGARET AS A LOVER OF LITERATURE.
}

HE great foundations of Christ's Col-
lege and St. John's College, at Cam-
bridge, are lasting monuments of
the wealth and liberality of Margaret
The education of women was still neglected in
her day, but the Lady Margaret was more fortunate
than some of her sisters. She learned French, but
her acquaintance with Latin, as she lamented, was
somewhat elementary, though she knew sufficient
to follow the church services. She had a good
memory and natural ability. She was a skilful and
artistic needlewoman. 'Right studious she was in
books, which she had in great number, both in
English and in French,' as Bishop Fisher testifies.
Some of her books we know by name. Ann,
Duchess of Buckingham, who was the Lady Mar-
garet's mother-in-law, died in I 480, and bequeathed
to her 'a book of English called "Legenda Sanc-
torum," a book of French called " Lucun," 2 another
book of French of the epistles and gospels, and a

' For fuller details as to the Lady Margaret, the memoir by C. A. Halsted and that by C. H. Cooper, edited by J. E. B. Mayor, must be consulted.

'Sir H. Nicolas prints this 'Lucum.' See ' Testamenta Vetusta,' p. 357. 
primer with clasps of silver gilt covered with purple velvet.' Professor J. E. B. Mayor has suggested that by 'Lucun' is meant the translation of Lucan, Sallust and Suetonius, printed for Vérard at Paris in 1490.

Bishop Fisher bears testimony to the devoutness and ascetic spirit of the Lady Margaret, but her austerities were not incompatible with the enjoyment of dramatic entertainments or the sports of an abbot of misrule that did right well his office. On the occasion of the marriage of Catharine of Aragon and Prince Arthur she was one of the spectators of a pageant in which one of the performers represented the Almighty, and delivered a sermon in verse. The Sunday entertainments included plays, dancing, dicing, carding, archery, etc. She had a band of minstrels under her patronage, and to these the town of Cambridge in $149 \mathrm{I}$ gave red wine at a charge of five pence. On 3 rd December, $1497, £_{3} 6$ s. $8 d$. was paid out of the King's privy purse 'to my lady King's moder poet.' And it has been suggested that Lady Margaret's laureate was Erasmus. We should like to think so.

The Lady Margaret was a patron of the first English printer, and of two of his successors. William Caxton tells us that he had sold to the Lady Margaret a copy of 'Blanchardine et Eglantine' in French, and at a later period she returned the book to him to be translated into English. This version he printed about 1489 with a dedication ' beseeching my said lady's bounteous grace to receive this little book in gree of me her humble servant and to pardon me of the rude and common 
English, wheras shall be found fault, for I confess me not learned, ne knowing the art of rhetoric, ne of such gay terms as now be said in these days and used. But I hope that it shall be understandon of the readers and hearers; and that shall suffice.' This last sentence is omitted by Blades. It may be noted that Caxton erroneously calls his patroness Duchess of Somerset, as though she had inherited the title as well as the estates of her father.

In 1494 an English version of Walter Hylton's 'Scala Perfectionis' was printed in the house of William Caxton by Wynkyn de Worde at the command of the Lady Margaret, as appears by some verses, strangely punctuated, at the end.

\section{Lenuoye.}

Infynite laude wyth thankynges many folde I yelde to god me socouryng wyth his grace This boke to finysshe whiche that ye beholde Scale of perfeccion calde in euery place Whereof thauctor walter Hilton was And wynkyn de worde this hath sett in prynt In willyam Caxtons hows so fyll the case God rest his soule. In Joy there mot it stynt

This heuenly boke more precyous than golde Was late direct wyth great humylyte For godly plesur. theron to beholde Unto the right noble Margaret as ye see The kyngis moder of excellent bounte Henry the seuenth that Jhü hym preserue This mighty pryncesse hath comaunded me Temprynt this boke her grace for to deserue.

At the 'exortacion and sterynge ' of the Countess, her confessor, Bishop Fisher, published his treatise 
on the seven penitential psalms, which was printed by Pynson in 1505 and 1510 , and by Wynkyn de Worde in $1508,1509,1525$, and 1529 . The bishop states that his patroness delighted greatly in these Psalms. Wynkyn de Worde in 1509 when he issued the 'Parlyament of Devils' and the 'Gospel of Nicodemus,' and in the colophons styles himself - Prynter vnto the moost excellent Pryncesse my lady the Kynges mother.'

Bishop Fisher's funeral sermon for Henry VII, preached at St. Paul's, Ioth March, 1509, was printed by Wynkyn de Worde at the special request of the Lady Margaret. ${ }^{1}$

Henry Watson, at the request of Wynkyn de Worde, who had been moved thereto by the Lady Margaret, translated Brant's 'Ship of Fools' from French into English, and although very inferior to Alexander Barclay's metrical version, this reached a second edition in 1517 . Pynson printed a 'Breviarium Sarisburiense' at the expense of the Countess, but the date is not known. Dyce suggests that 'my lady's grace,' whom Skelton mentions as the patroness of his last translation from French into English prose ' Of Mannes Lyfe the' Peregrynacioun,' was the Lady Margaret.

The Lady Margaret was not only a patron of literature, but a labourer therein. Perhaps we ought to reckon among her literary efforts the 'Ordinances and Reformations of Apparel for Princes and estates with other ladies and gentlewomen for the

1 This sermon and that by the same prelate for the Lady Margaret are said to be the earliest printed examples of that form of literature. 


\section{$3^{8}$ THE LADY MARGARET AS A}

time of mourning,' of which there are several manuscript copies. The Statutes of Christ's College are said to be 'framed' by the Countess in I 506, but, as they are in Latin, we may conclude that they were not her composition. The very detailed comparison of a college and the various parts of the human body appears to have been a commonplace of the period. ${ }^{\text {. }}$.

By the 'request and commandment of the Lady Margaret,' a translation from the Latin of the 'Imitatio Christi' was made by Dr. William Atkynson, and printed 'by Wynkynde Worde in Fleet Street at the sign of the Sun.' The fourth book was translated by the Lady Margaret from the French, and printed by the same printer in $1504 .^{1}$

As a specimen of her skill as a translator, it may suffice to give the last paragraph of her translation. We give the Latin text, Lady Margaret's rendering from the French, and Dr. W. A. Copinger's 'absolutely literal translation of the original.'

Nam fides et amor ibi maximè praecellunt, et occultis modis in hoc sanctissimo et superexcellentissimo sacramento operantur. Deus aeternus et immensus, infinitaeque potentiae, facit magna et inscrutabilia in coelo et in terra, nec est investigatio mirabilium operum ejus. Si talia essent opera Dei, ut facilè ab humana ratione caperentur, non esset mirabilia nec ineffabilia dicenda.

Cooper, PP, 101, 251.

This is included in Dr. J. K. Ingram's early English edition of the 'De Imitatione Christi' (Early English Text Society's extra series, lxiii, 1893 ). 


\section{Lady Margaret's Version.}

Fast faith and true love surmounteth all curious inquisition, principally in this matter, and marvellously openeth to understanding in secret manner of this holy and right excellent sacrament. O eternal God, and without measure of might and bounty, which hast made the infinite great and wonderful things in the heaven and earth, which none is sufficient to inquire, understand or find the secrets of thy so marvellous works, and therefore they be called inestimable, for man's reason neither may nor can comprehend thy works. To whom, Lord God Almighty, be given laud and praising withouten end.

\section{Dr. Copenger's Version.}

For faith and love here shine forth most abundantly and work in hidden ways in this most holy and transcendent Sacrament. God who is eternal and incomprehensible and of infinite power, doth things inscrutable in heaven and earth and there is no searching out of His wonderful works. If the works of God were such as might be easily comprehended by human reason, they could neither be called wonderful nor unspeakable.

Here it is easy to see that in the diffuse version of the Lady Margaret there is the influence of a modern language less compact in its structure than the Latin. The only word she uses that can be regarded as obsolete is withouten. The rest of her vocabulary is absolutely modern, although it is more than four centuries since she wrote the paragraph we have quoted.

About 1507 appeared 'The Mirroure of Golde for the sinfull Soule,' which she had turned from a French version into English. It was printed by Pynson and several times reprinted. 
This presente boke (we quote from the edition of 1 522) is called the Mirroure of golde to $y^{\circ}$ sinfull soule/ the whiche hath ben trāslated at parice oute of laten into frenche/ and after the träslation seen \& corrected/at length of many clarkis/ Doctours/ \& maisters in diuinitie/ and nowe of late translatede oute of frenche ito Englisshe by the right excellèt princesse Margarete moder to oure souerain lorde kinge Henry the .vii. and Countesse of Richemond \& derby.

The British Museum Catalogue describes it as a translation of the 'Speculum aureum animae peccatricis' of Denis de Leeuwis, de Rickel. 'This author, known as the 'Doctor Extaticus,' whose name was latinized as Dionysius à Leewis, was born at Rickel, in the bishopric of Liége in 1394 and died in 1471 . He was educated at Cologne, joined the Carthusian order, and was the author of above a hundred theological books. Some of these are controversial, but for the most part his writings are exegetical or didactic. In 1608 his body was exhumed by an admiring bishop, and the bones were for the most part still adherent. Foppens adds: 'Et, quod tota miretur posteritas, pollex et index manus dexterae, duo nimirum scriptendorum librorum instrumenta maximè necessaria, integri, carnosi et vividi.' 1

The Lady Margaret's will further illustrates her claims as a lover of literature. To her chapel at Westminster she left a 'portuous,' and a book having in the beginning certain images with prayers to them; and after them the primer and psalter. These were to be chained. To Durham monastery she left a

' Foppens: 'Bibliotheca Belgica,' i, 244. 
Sarum mass book. A mass book was bequeathed to the parish of Colyweston. To the King she left 'a French book of vellum with diverse stories, at the beginning the book of Genesis with pictures limned, a great volume of vellum covered with black velvet which is the second volume of Froissart, a great volume of vellum named John Bokas lymned, and a great volume of vellum of the siege of Troy in English.' We need not suppose Boccaccio's book to have been the 'Decamerone'; it is more likely to have been Lydgate's translation of the 'Falls of Princes,' and the following item to have been his 'Troy book.' John St. John became the happy possessor of a book of vellum of 'Canterbury Tales' in English. Alexander Frognall received 'a printed book which is called Magna Carta in French.' In the executors' accounts books are mentioned, but the titles are not specified.

Truly the memory of the Lady Margaret should be had in honour and grateful remembrance by the lovers of literature and learning.

William E. A. Axon. 